archives-ouvertes

\title{
Shielding effects in thin films of carbon nanotubes within microwave range
}

Alesia Paddubskaya, Mikhail Shuba, Gintaras Valušis, Polina Kuzhir, Sergey

Maksimenko, Alexander Vladimirovich Okotrub, Emmanuel Flahaut, Anne

Marie Galibert, Brigitte Soula, Vanessa Fierro, et al.

\section{To cite this version:}

Alesia Paddubskaya, Mikhail Shuba, Gintaras Valušis, Polina Kuzhir, Sergey Maksimenko, et al.. Shielding effects in thin films of carbon nanotubes within microwave range. Lithuanian Journal of Physics, Lietuvos mokslu akademija, 2016, vol. 56 ( $\left.{ }^{\circ} 2\right)$, pp. 86-91. 10.3952/physics.v56i2.3304 . hal-01452086

\section{HAL Id: hal-01452086 \\ https://hal.archives-ouvertes.fr/hal-01452086}

Submitted on 1 Feb 2017

HAL is a multi-disciplinary open access archive for the deposit and dissemination of scientific research documents, whether they are published or not. The documents may come from teaching and research institutions in France or abroad, or from public or private research centers.
L'archive ouverte pluridisciplinaire HAL, est destinée au dépôt et à la diffusion de documents scientifiques de niveau recherche, publiés ou non, émanant des établissements d'enseignement et de recherche français ou étrangers, des laboratoires publics ou privés. 


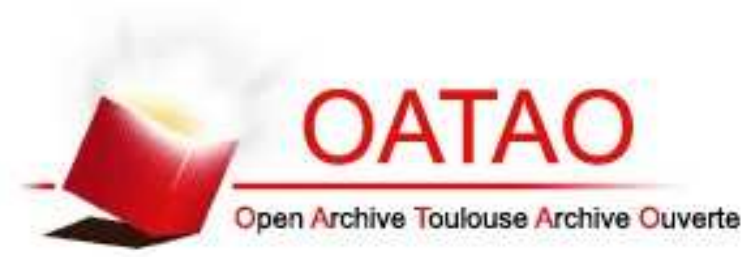

\section{Open Archive TOULOUSE Archive Ouverte (OATAO)}

OATAO is an open access repository that collects the work of Toulouse researchers and makes it freely available over the web where possible.

This is an author-deposited version published in : http://oatao.univ-toulouse.fr/ Eprints ID : 16793

To link to this article : DOI : 10.3952/physics.v56i2.3304

URL : http://dx.doi.org/10.3952/physics.v56i2.3304

To cite this version : Paddubskaya, Alesia and Shuba, Mikhail and Valušis, Gintaras and Kuzhir, Polina and Maksimenko, Sergey and Okotrub, Alexander Vladimirovich and Flahaut, Emmanuel and Galibert, Anne Marie and Soula, Brigitte and Fierro, Vanessa and Celzard, Alain Shielding effects in thin films of carbon nanotubes within microwave range. (2016) Lithuanian Journal of Physics, vol. 56 ( $\mathrm{n}^{\circ}$ 2). Pp. 86-91. ISSN 1648-8504

Any correspondence concerning this service should be sent to the repository administrator: staff-oatao@ listes-diff.inp-toulouse.fr 


\title{
SHIELDING EFFECTS IN THIN FILMS OF CARBON NANOTUBES WITHIN MICROWAVE RANGE
}

\author{
A. Paddubskaya ${ }^{\text {a }}$, M. Shuba ${ }^{b}$, G. Valušis ${ }^{a}$, P. Kuzhir ${ }^{b}$, S. Maksimenko ${ }^{b}$, A. Okotrub ${ }^{c}$, \\ E. Flahaut ${ }^{\text {d, A.M. Galibert }}{ }^{\mathrm{d}}$, B. Soula ${ }^{\mathrm{d}}$, V. Fierro ${ }^{\mathrm{e}}$, and A. Celzard ${ }^{\mathrm{e}}$ \\ ${ }^{a}$ Center for Physical Sciences and Technology, Savanoriu 231, LT-01108 Vilnius, Lithuania \\ ${ }^{b}$ Institute for Nuclear Problems, Belarus State University, Bobruiskaya Str. 11, 220050 Minsk, Belarus \\ 'Nikolaev Institute of Inorganic Chemistry, Siberian Branch of Russian Academy of Sciences, Acad. Lavrentiev Ave. 3, \\ 630090 Novosibirsk, Russia \\ ${ }^{\mathrm{d}}$ University de Toulouse; CNRS/UPS/INP; Institut Carnot CIRIMAT, 118, route de Narbonne, \\ F-31062 Toulouse Cedex 9, France \\ ' Institut Jean Lamour - UMR CNRS - Université de Lorraine 7198, ENSTIB, 27 rue Philippe Seguin, CS 60036, \\ 88026 Epinal Cedex, France \\ E-mail: paddubskaya@gmail.com
}

\begin{abstract}
The electromagnetic shielding properties of thin films comprising different types of carbon nanotubes (CNTs) were analysed in the microwave frequency range $(26-36 \mathrm{GHz})$. A comparative analysis of the shielding properties was achieved for films based on long and short single-, double- and multi-walled CNTs. The experimental results proved that long-length single-walled CNTs demonstrate the highest interaction with the electromagnetic (EM) field, thereby providing the best shielding efficiency. At the same time, double-walled CNTs demonstrate a higher level of absorption ability (50\%) along with the overall high EM shielding efficiency (88\%), which makes them attractive for using in nanoelectronics screens as they produce the smallest secondary EM pollution.
\end{abstract}

Keywords: microwave frequency range, electromagnetic response, carbon nanotubes

\section{Introduction}

Progresses in nanoscience and nanotechnology continuously allow developing new applications, including communications and electronics. The development of new ultra-light and low-cost shielding nanomaterials for the microwave frequency range is a current task for improving the reliability of electronic equipment. This is the reason why intensive investigations of the shielding effect are carried out for new types of composite materials based on graphite, graphene [1], carbon nanotubes [2-4] and other fillers.

Due to a unique combination of high electrical conductivity, resistance to corrosion, flexibility, lightness and mass-production ability, composites based on polymer matrices containing conductive fillers are among the most attractive materials for shielding applications. As for various kinds of available conductive inclusions, carbon nanoparticles (amorphous carbon, graphene, fullerenes, carbon nanotubes, etc.) are considered to be the most promising for developing efficient electromagnetic shielding materials. As already shown in our previous research works [5-8], carbon nanotubes (CNTs) are among the best candidates for designing EM shielding polymer materials, owing to their high aspect ratio $(\sim 1000)$ and unique electronic properties. Shielding effectiveness (SE) of CNT-based composites depends on the type of polymer matrix and on the characteristics of CNTs such as length [9], diameter [5, 10], and orientation [11]. However, composite production with a homogeneous distribution of CNTs in the matrix is still a non-trivial problem, due to the strong tendency of CNT to agglomerate. Such effect limits the CNT concentration in the composites and lowers the total EM effectiveness of the material.

In addition to composites prepared by means of traditional processes, e. g. by mixing polymers with CNT suspensions, other hybrid materials were recently 
developed [12]. Thus, based on the idea that higher EM shielding might be obtained by using high concentration of separated CNTs (or their bundles), Wu et al. avoided the agglomeration problems and fabricated CNT microfilms on a polymer substrate (like sandwich structures) presenting high shielding effectiveness (SE up to $61-67 \mathrm{~dB}$ ) in the $X$ band $[13,14]$. Wang et al. presented a screen printing technique for the commercial fabrication of low-cost thin CNT films on a polymer substrate with high shielding performances [15].

Unlike usual composites, for which EM properties mostly depend on those of CNT agglomerates and of small amounts of isolated CNTs, the shielding effectiveness of thin films is more sensitive to CNT geometrical parameters. In spite of numerous publications related to traditional CNT-based polymer composites, the proper choice of optimal parameters is still a problem to be solved and it motivated our investigations. In the present paper, we compared microwave properties of thin films comprising CNTs of different lengths and different natures (single-walled, double-walled and multi-walled CNTs).

\section{Materials and methods}

Single-walled CNTs (SWCNTs) produced by gasphase catalysis (HiPco process) were purchased from NanoIntegris Inc. (http://www.nanointegris.com). The average diameter of individual SWCNTs was $0.8-1.2 \mathrm{~nm}$ and their length was $\sim 1 \mu \mathrm{m}$. Doublewalled CNTs (DWCNTs) were synthesized at CIRIMAT (Toulouse, France) by catalytic chemical vapour deposition (CCVD) through decomposition of $\mathrm{CH}_{4}$ over a $\mathrm{Mg}_{1-x} \mathrm{Co}_{x} \mathrm{O}$ solid solution containing small amounts of molybdenum [16, 17]. The DWCNT length was $1-10 \mu \mathrm{m}$ (although bundles could measure up to $100 \mu \mathrm{m}$ ) with an outer diameter of $1-3 \mathrm{~nm}$, and the sample contained $80 \%$ DWCNTs. Multiwalled CNTs (MWCNTs) were produced by the CVD method (Baytubes ${ }^{\circ} \mathrm{150P}$, Bayer MaterialScience AG, Germany). As specified by the supplier, MWCNTs had inner and outer diameters of about $4 \pm 2$ and $11 \pm 3 \mathrm{~nm}$, respectively. The MWCNT length was more than $1 \mu \mathrm{m}$.

Short-length CNTs were produced by cutting long-length CNTs using the procedure detailed elsewhere [18]. Atomic force microscopy (AFM, Solver P47 PRO, NT-MDT Inc) showed that intensive ultrasonication in an acid mixture $\left(95 \% \mathrm{H}_{2} \mathrm{SO}_{4}\right.$ and $59 \%$ $\mathrm{HNO}_{3}$ at volume fractions of 8:1, respectively) at low temperature $\left(<8^{\circ} \mathrm{C}\right)$ allowed reducing the $\mathrm{CNT}$ length down to $100-300 \mathrm{~nm}$ for all kinds of tubes, without a significant change of their diameter distribution or modification of their electronic properties (Fig. 1).
CNTs films were fabricated by the vacuum filtration technique [19-22] as follows.

- $0.2 \mathrm{mg}$ of each type of CNTs was dispersed into 1 wt.\% of sodium dodecyl sulfate (Sigma-Aldrich) in water by ultra-sonication $(44 \mathrm{kHz})$ for $1 \mathrm{~h}$. Then,

(a)

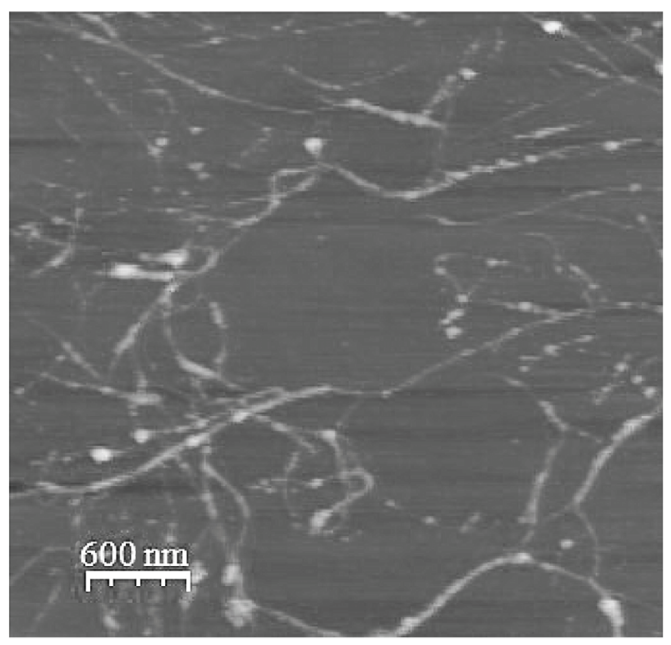

(b)

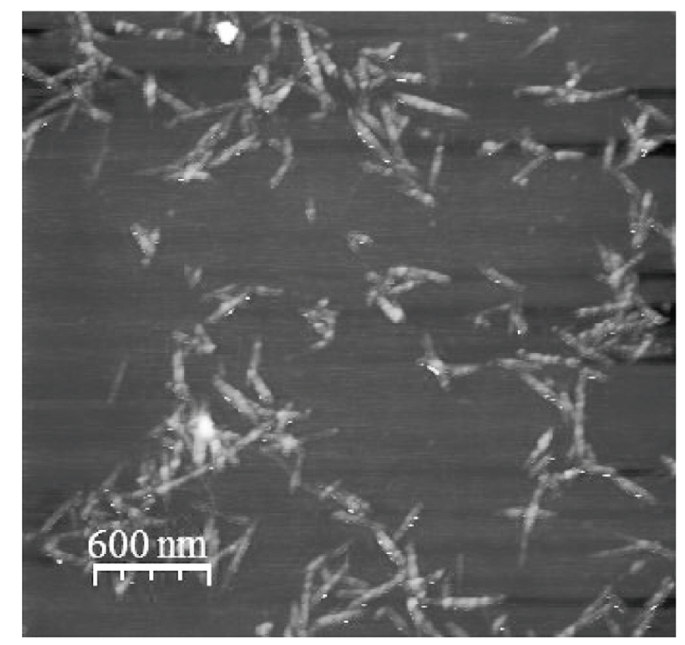

Fig. 1. AFM images of SWCNTs before (a) and after (b) cutting.

in order to separate them from undissolved CNTs bundles and from impurities (e. g. small amounts of amorphous carbon and catalytic particles), centrifugation was carried out for $10 \mathrm{~min}$ at $12000 \mathrm{~g}$.

- After the centrifugation the supernatant was collected and then filtered with a cellulose acetate membrane (Millipore, $0.22 \mu \mathrm{m}$ pore size). During the filtration process, the CNTs accumulated on the membrane surface, forming a homogeneous film.

- The surfactant was washed away with pure water. Finally, the filtration membrane was dissolved in acetone, the film was washed with water, and then transferred onto $10 \mu \mathrm{m}$-thick Teflon substrates. The substrate is almost transparent in the microwave frequency range and does not contribute to the total electromagnetic response of the investigated samples. 
In order to measure the thickness of obtained films, a small part of each one was also transferred onto a silica substrate. The average thickness of each film was then determined with a digital profilometer Veeco Dektak 6M and is given in Table 1.

Table 1. Measured average thickness for each CNT film.

\begin{tabular}{c|c|c|c}
\hline & SWCNT & DWCNT & MWCNT \\
\cline { 2 - 4 } & $\begin{array}{c}\text { Long/short } \\
\text { length }\end{array}$ & $\begin{array}{c}\text { Long/short } \\
\text { length }\end{array}$ & $\begin{array}{c}\text { Long/short } \\
\text { length }\end{array}$ \\
\hline Thickness, nm & $560 / 800$ & $500 / 700$ & $610 / 775$ \\
\hline
\end{tabular}

The microwave measurements of transmission/ reflection coefficients in the Ka-band $(26-36 \mathrm{GHz})$ were performed with a scalar network analyzer R2408 (ELMIKA) after inserting the sample under study into a transmission line (waveguide of cross-section $7.2 \times 3.4 \mathrm{~mm}$ ) perpendicular to wave propagation [23] The EM response of samples was measured as ratios of transmitted to input $\left(S_{21}\right)$ and reflected to input $\left(S_{11}\right)$ signals.

\section{Results and discussion}

The measured electromagnetic response $\left(S_{11}\right.$ and $\left.S_{21}\right)$ of thin films based on long-length and short-length SWCNTs is presented in Fig. 2. Frequency dependences of $S$-parameters for both types of SWCNT films were flat and did not show any special feature such as absorption peak or other trends. The same behaviour was observed for other composites based on DWCNTs and MWCNTs, and therefore the electromagnetic response was analyzed only at one frequency $(30 \mathrm{GHz})$.

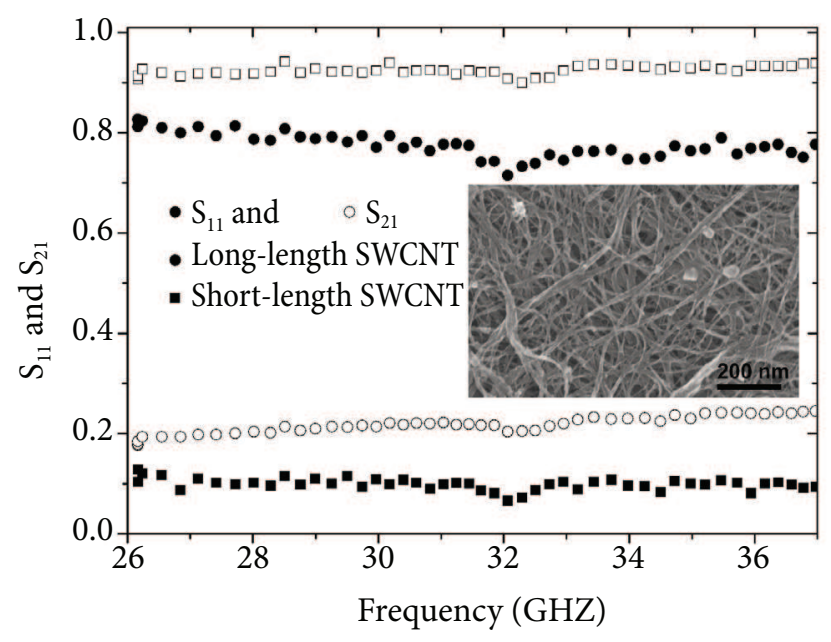

Fig. 2. Frequency dependence of $S_{11}$ and $S_{21}$. Inset: scanning electron microscope image of a long-length SWCNT film. As can be seen, ultracentrifugation removed large particles and agglomerates, providing high-quality CNT films.
Reflectance $\left(R=S_{11}^{2}\right)$, transmittance $\left(T=S_{21}^{2}\right)$ and absorbance $(A=1-T-R)$ of the electromagnetic radiation as well as the total shielding effectiveness $\left(\mathrm{SE}=-20 \log \left(S_{21}\right)\right)$ at $30 \mathrm{GHz}$ for films comprising different natures of CNTs (SWCNTs, DWCNTs and MWCNTs) and lengths are presented in Fig. 3.

Our results reveal that thin films based on $200 \mathrm{~nm}$ long CNTs are transparent to microwave radiation $(T \sim 84-92 \%)$ and give a negligible attenuation level ( $\mathrm{SE} \sim 0.35-0.75 \mathrm{~dB}$ ). It can be noticed that, in this case, such high transparency does not depend on the type of CNTs used for film fabrication.

(a)

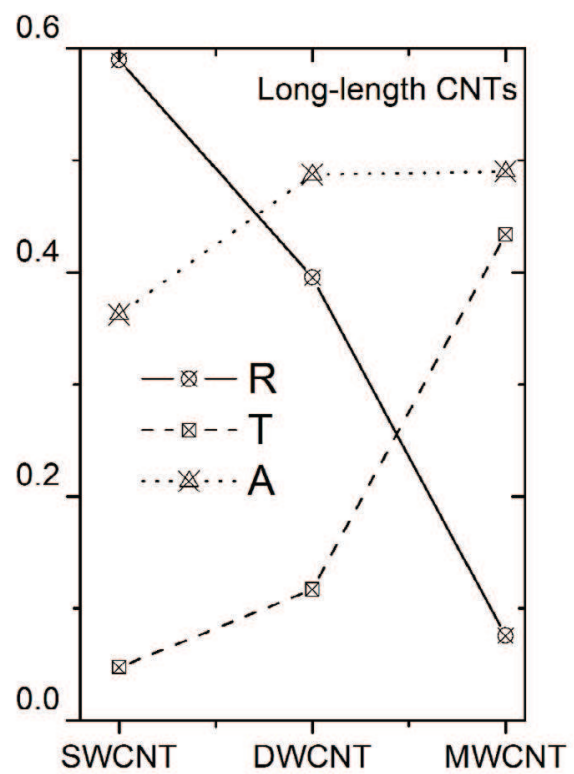

(b)

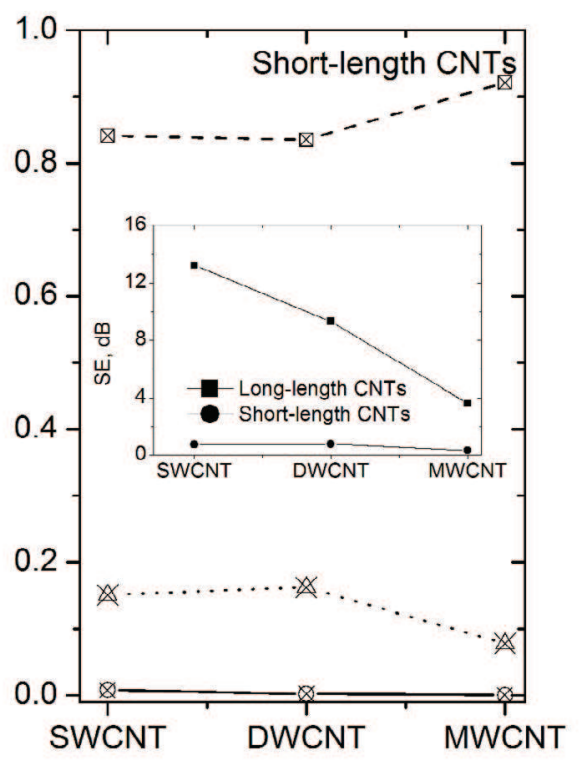

Fig. 3. Absorbance $A$, reflectance $R$ and transmittance $T$ at $30 \mathrm{GHz}$ of films based on CNTs: (a) long-length CNTs, (b) short-length CNTs. The inset shows the corresponding SE. 
Figure 3 shows that the SE of films based on SWCNTs is $13 \mathrm{~dB}$, and decreased down to $3.62 \mathrm{~dB}$ as the number of walls increased. Such attenuation level was achieved due to high levels of both reflectance (58\%) and absorbance (36\%).

This result agrees with our previous theoretical predictions [7]. Indeed, as it has been shown earlier, the electromagnetic properties of composites are mostly determined by the polarizability $\alpha$ of the individual inclusions. The imaginary part of the polarizability $\alpha$ has a peak in the terahertz range $(1.5-6 \mathrm{THz})$. The frequency position $f_{p}$ of this peak depends on both length and diameter of CNTs. As demonstrated in [7], the frequency $f_{p}$ splits the spectra into two different parts: quasistatic and dynamic regimes. In the quasi-static regime $\left(f \leq f_{p}\right)$, the CNT polarizability is strongly influenced by the finite-length effect, leading to a strong screening as outermost shells screen the internal ones. Such a strong screening effect in the case of short-length tubes explains the transparency $(T>80 \%)$ of the corresponding films as well as the absence of dependence on the type of CNTs. The increase in CNT length decreases the impact of such finite-length effect, resulting in the increase in the electromagnetic absorption from a moderate level of $15 \%$ up to $36-49 \%$. As it was mentioned, the real part of the polarizability of long-length MWCNTs is larger than that of SWCNTs, but the substantial difference in reflection of thin films (58\% against $1 \%$ for SWCNT- and MWCNT-based films, respectively) and high shielding effectiveness can be explained by a significant difference in their number density.

To conclude, the strong influence of the nanotube length and the number of walls on the electromagnetic response of thin CNT-based films was evidenced in the microwave frequency range. It has been shown that the thin films based on short-length nanotubes demonstrated the negligible attenuation level due to the strong depolarizing field and screening effect in CNT. The opposite was observed for the films based on long-length CNTs. The analysis of the obtained dependence for different types of nanotubes allowed us to conclude that the films based on long-length SWCNTs are more preferable in case we are looking for overall high attenuation ability (the transmission rate is less than $5 \%$ because of $60 \%$ reflection and 35\% absorption for the film being approx. 500-600 nm thick). However, films made of double-walled CNTs are much more absorptive in comparison with SWCNT ones (50 vs 35\%), which makes them in some sense more attractive as they do produce much smaller additional EM interference. Finally, MWCNTs demonstrate the smallest EMI shielding efficiency out of the three families of tubes investigated here, at the level of $55 \%$, but still absorptive (50\%), which also makes them suitable.

\section{Acknowledgements}

This research was partially supported by projects FP7316633 POCAONTAS, the Belarus Republican Foundation for Fundamental Research (BRFFR) under projects F14R-026, and the Russian Foundation for Basic Research under project No. 14-03-90028.

\section{References}

[1] N. Yousefi, X. Sun, X. Lin, X. Shen, J. Jia, B. Zhang, B. Tang, M. Chan, and J.-K. Kim, Highly aligned graphene/polymer nanocomposites with excellent dielectric properties for high-performance electromagnetic interference shielding, Adv. Mater. 26, 5480-5487 (2014), http://dx.doi.org/10.1002/ adma.201305293

[2] P. Verma, P. Saini, and V. Choudhary, Designing of carbon nanotube/polymer composites using melt recirculation approach: effect of aspect ratio on mechanical, electrical and EMI shielding response, Mater. Des. 88, 269-277 (2015), http:// dx.doi.org/10.1016/j.matdes.2015.08.156

[3] M. Dragoman, K. Grenier, D. Dubuc, L. Bary, E. Fourn, R. Plana, and E. Flahaut, Experimental determination of microwave attenuation and electrical permittivity of double-walled carbon nanotubes, Appl. Phys. Lett. 88(15), 153108 (2006), http://dx.doi.org/10.1063/1.2193464

[4] F. Bourdiol, D. Dubuc, K. Grenierc, F. Mouchet, L. Gauthier, E. Flahaut, Quantitative detection of carbon nanotubes in biological samples by an original method based on microwave permittivity measurements, Carbon 81, 535-545 (2015), http:// dx.doi.org/10.1016/j.carbon.2014.09.086

[5] A.G. Paddubskaya, P.P. Kuzhir, V.L. Kuznetsov, I.N. Mazov, S.I. Moseenkov, A.V. Ishchenko, A.I. Romanenko, O.B. Anikeeva, and T.I. Buryakov, CNT/PMMA electromagnetic coating: effect of carbon nanotube diameter, Fuller. Nanotub. Carbon Nanostr. 20, 527-530 (2012), http://dx.doi.org/10.1 080/1536383X.2012.656054

[6] A. Paddubskaya, D. Bychanok, A. Plyushch, P. Kuzhir, A. Nemilentsau, S. Maksimenko, S. Bellucci, L. Coderoni, F. Micciulla, I. Sacco, G. Rinaldi, J. Macutkevic, D. Seliuta, G. Valusis, and J. Banys, Epoxy resin/SWCNT shielding paint for super-high-frequency range, J. Nanoelectron. Optoelectron. 7(1), 81-86 (2012), http://dx.doi. org/10.1166/jno.2012.1222

[7] M.V. Shuba, A.V. Melnikov, A.G. Paddubskaya, P.P. Kuzhir, and S.A. Maksimenko, Role of finitesize effects in the microwave and subterahertz electromagnetic response of a multiwall carbonnanotube-based composite: Theory and interpretation of experiments, Phys. Rev. B 88(4), 045436 (2013), http://dx.doi.org/10.1166/jno.2012.1222 
[8] S. Pacchini, D. Dubuc, E. Flahaut, and K. Greniera, Double-walled carbon nanotube-based polymer composites for electromagnetic protection, Int. J. Microw. Wirel. Technol. 2(5), 487-495 (2010), http://dx.doi.org/10.1017/S1759078710000668

[9] J.B. Bai and A. Allaoui, Effect of the length and the aggregate size of MWNTs on the improvement efficiency of the mechanical and electrical properties of nanocomposites - experimental investigation, Compos. A 34(8), 689-694 (2003), http:// dx.doi.org/10.1016/S1359-835X(03)00140-4

[10]I. Dubnikova, E. Kuvardina, V. Krasheninnikov, S. Lomakin, I. Tchmutin, and S. Kuznetsov, The effect of multiwalled carbon nanotube dimensions on the morphology, mechanical, and electrical properties of melt mixed polypropylene-based composites, J. Appl. Polym. Sci. 117(1), 259-272 (2010), http://dx.doi.org/10.1002/app.31979

[11]D.S. Bychanok, M.V. Shuba, P.P. Kuzhir, S.A. Maksimenko, V.V. Kubarev, M.A. Kanygin, O.V. Sedelnikova, L.G. Bulusheva, and A.V. Okotrub, Anisotropic electromagnetic properties of polymer composites containing oriented multiwall carbon nanotubes in respect to terahertz polarizer applications, J. Appl. Phys. 114(11), 114304 (2013), http://dx.doi.org/10.1063/1.4821773

[12]L. Liu, L.B. Kong, W.Y. Yin, and S. Matitsine, Characterization of single- and multiwalled carbon nanotube composites for electromagnetic shielding and tunable applications, IEEE Trans. Electromagn. Compat. 53(4), 943-949 (2011), http://dx.doi.org/10.1109/TEMC.2011.2159798

[13] Z.P. Wu and J.N. Wang, Preparation of largearea double-walled carbon nanotube films and application as film heater, Physica E 42(1), 77-81 (2009), http://dx.doi.org/10.1016/j.physe.2009.09.003

[14]Z.P. Wu, M.M. Li, Y.Y. Hu, Y.S. Li, Z.X. Wang, Y.H. Yin, Y.S. Chen, and X. Zhou, Electromagnetic interference shielding of carbon nanotube macrofilms, Scripta Mater. 64(9), 809-812 (2011), http:// dx.doi.org/10.1016/j.scriptamat.2011.01.002

[15] L.L. Wang, B.K. Tay, K.Y. See, Z. Sun, L.K. Tan, and D. Lua, Electromagnetic interference shielding effectiveness of carbon-based materials prepared by screen printing, Carbon 47(8), 1905-1910 (2009), http://dx.doi.org/10.1016/j.carbon.2009.03.033

[16]E. Flahaut, R. Bacsa, A. Peigney, and C. Laurent, Gram-scale CCVD synthesis of double-walled carbon nanotubes, Chem. Commun. 1442-1443 (2003), http://dx.doi.org/10.1039/B301514A

[17]E. Flahaut, A. Peigney, W.S. Bacsa, R.R. Bacsa, and C. Laurent, CCVD synthesis of carbon nanotubes from ( $\mathrm{Mg} \mathrm{Co}, \mathrm{Mo}) \mathrm{O}$ catalysts: influence of the proportions of cobalt and molybdenum, J. Mater. Chem. 14(4), 646-653 (2004), http:// dx.doi.org/10.1039/B312367G

[18]M.V. Shuba, A.G. Paddubskaya, P.P. Kuzhir, S.A. Maksimenko, V.K. Ksenevich, G. Niaura, D. Seliuta, I. Kasalynas, and G. Valusis, Soft cutting of singlewall carbon nanotubes by low temperature ultrasonication in a mixture of sulfuric and nitric acids, Nanotechnol. 23(49), 495714 (2012), http://dx.doi. org/10.1088/0957-4484/23/49/495714

[19]Z. Wu, Z. Chen, X. Du, J.M. Logan, J. Sippel, M. Nikolou, K. Kamaras, J.R. Reynolds, D.B. Tanner, A.F. Hebard, and A.G. Rinzler, Transparent, conductive carbon nanotube films, Science 305(5688), 1273-1276 (2004), http://dx.doi.org/10.1126/science.1101243

[20]S.Y. Chew, S.H. Ng, J. Wang, P. Nova'k, F. Krumeich, S.L. Chou, J. Chend, and H.K. Liu, Flexible freestanding carbon nanotubes films for model lithiumion batteries, Carbon 47(13), 2976-2983 (2009), http://dx.doi.org/10.1016/j.carbon.2009.06.045

[21] F. Hennrich, S. Lebedkin, S. Malik, J. Tracey, M. Barczewski, H. Roesner, and M. Kappes, Preparation, characterization and applications of free-standing single walled carbon nanotube thin films, Phys. Chem. Chem. Phys. 4(11), 2273-2277 (2002), http://dx.doi.org/10.1039/B201570F

[22]F. Hennrich, R. Wellmann, S. Malik, S. Lebedkin, and M. Kappes, Reversible modification of the absorption properties of single-walled carbon nanotube thin films via nitric acid exposure, Phys. Chem. Chem. Phys. 5(1), 178-183 (2003), http:// dx.doi.org/10.1039/B208270E

[23] L.F. Chen, C.K. Ong, C.P. Neo, V.V. Varadan, and V.K. Varadan, Microwave Electronics: Measurement and Materials at Microwave Frequencies (John Wiley \& Sons, UK, 2004). 


\title{
EKRANAVIMO REIŠKINIAI PLONUOSIUOSE ANGLIES NANOVAMZDELIŲ SLUOKSNIUOSE MIKROBANGŲ RUOŽE
}

\author{
A. Paddubskaya ${ }^{\text {a }}$, M. Shuba ${ }^{\text {b }}$, G. Valušis ${ }^{\text {a }}$, P. Kuzhir ${ }^{\text {b }}$, S. Maksimenko ${ }^{\text {b }}$, A. Okotrub ${ }^{\text {c }}$, E. Flahaut ${ }^{\text {, }}$, \\ A.M. Galibert ${ }^{\mathrm{d}}$, B. Soula ${ }^{\mathrm{d}}$, V. Fierro ${ }^{\mathrm{e}}$, A. Celzard ${ }^{\mathrm{e}}$ \\ ${ }^{a}$ Fiziniu ir technologijos mokslų centras, Vilnius, Lietuva \\ ${ }^{b}$ Baltarusijos valstybinis universitetas, Minskas, Baltarusija \\ ${ }^{c}$ Rusijos mokslu akademijos Sibiro skyriaus Nikolajevo neorganines chemijos institutas, Novosibirskas, Rusija \\ ${ }^{d}$ Tulūzos universitetas, Prancūzija \\ ${ }^{e}$ Lotaringijos universitetas, Prancūzija
}

\section{Santrauka}

Naujų ultralengvų ir mažų gamybos sąnaudų reikalaujančių nanomedžiagų paieška bei tyrimai yra vienas svarbiausių uždavinių gerinant mikrobangų ruožo elektroninių prietaisų darbo patikimumą. Šiame darbe tyrinejjami ekranavimo reiškiniai plonuosiuose sluoksniuose, sudarytuose iš itvairaus ilgio vienasienių, dvisienių ir daugiasienių anglies nanovamzdelių. Eksperimentiniai tyrimai 26-36 GHz dažnių ruože parodè, kad ekranavimo efektyvumas priklauso nuo anglies nanovamzdelių ilgio. Ilgi nanovamzdeliai intensyviai sąveikauja su mikrobangų elektromagnetiniu lauku ir užtikrina didžiausią ekranavimo efektyvumą. Sluoksniuose su trumpais anglies nanovamzdeliais stebimas silpnas slopinimas dèl stipriai pasireiškiančio depoliarizacijos efekto. Lyginant rezultatus prieita prie išvados, kad ilgi pavieniai anglies nanovamzdeliai labiau tinkami bendram efektyviam ekranavimui (88 \% efektyvumas), dvisieniai nanovamzdeliai geriau absorbuoja mikrobangų spinduliuotę (50\% absorbcija), todel tinkami naudoti kaip nanoelektriniai ekranai, padedantys išvengti papildomos elektromagnetinių bangų interferencijos, o daugiasieniai nanovamzdeliai ekranuoja mažiausia (55 \% efektyvumas), bet išlieka tinkama absorbuojanti nanomedžiaga tirtajame dažnių ruože. 